\title{
Kaz Eti Tüketim Tercihleri ve İkame Ürünlerle Duyusal Analiz*
}

\author{
Selim Gündüz ${ }^{1}$, Celile Dölekoğlu ${ }^{2 \dagger}$, Dilek Say ${ }^{3}$ \\ ${ }^{1}$ Adana Alpaslan Türkeş Bilim ve Teknoloji Üniversitesi, İşletme Fakültesi, İşletme Bölümü Sarıçam/Adana (ORCID: 0000-0001-5289-6089) \\ ${ }^{2}$ Adana Alpaslan Türkeş Bilim ve Teknoloji Üniversitesi, İşletme Fakültesi, İşletme Bölümü Sarıçam/Adana (ORCID: 0000-0003-4421-2956) \\ ${ }^{3}$ Çukurova Üniversitesi, Pozantı MYO, Pozantı/Adana (ORCID: 0000-0003-3932-6414)
}

(İlk Geliş Tarihi 1 Mayıs 2019 ve Kabul Tarihi 20 Mayıs 2019)

(DOI: $10.31590 /$ ejosat.565364)

ATIF/REFERENCE: Gündüz. S, Dölekoğlu, C. ve Say, D. (2019). Kaz Eti Tüketim Tercihleri ve İkame Ürünlerle Duyusal Analiz. Avrupa Bilim ve Teknoloji Dergisi, (16), 32-40.

\section{$\ddot{O} \mathbf{z}$}

Dünyada ve Türkiye'de kaz yetiştiriciliği, diğer kümes hayvanlarına nazaran üreme seviyelerinin düşük olması sebebiyle geride kalmıştır. Ancak, kaz etinin önemli düzeydeki besleyici değeri, yüksek protein seviyesi, düşük kolesterol içeriği, karaciğerinin zengin vitamin değerine sahip olması ve kaz tüyünün de oldukça kıymetli olması kaz yetiştiriciliğinin önemini de son yıllarda artırmıştır. Birçok ülkede kaz eti tüm bu özellikleri nedeniyle tüketilmesine rağmen Türkiye'de sadece belirli bölgelerde yöresel kültürün bir parçası olarak tüketilmekte ve ülke genelinde yeterince tanınmamaktadır. Bu çalışmada, geleneksel ve arka bahçe yetiştiriciliği ile Doğu ve Orta Anadolu bölgelerinde üretilen ve tüketilen kazın son yıllarda farklı bölgelerde de talep edilmesi ile özellikle iç ve dış piyasada önemli bir pazar yaratacağı öngörüsüyle, kaz eti tüketimi ile ilgili duyusal analiz ve tüketim araştırması yapılması amaçlanmıştır. Çalışmanın materyalini Kars, Ardahan ve Iğdır illerinden katılımcıların oluşturduğu, Adana'da organize edilen "Geleneksel Kaz Gecesi" etkinliğine katılanlar arasından kolayda örnekleme tekniği ile seçilen 363 kişiyle yüz yüze görüşme tekniği ile gerçekleştirilen anket formlarından elde edilen veriler oluşturmaktadır. Anketler, kaz etinin kırmızı et, tavuk eti ve hindi etine göre görünüş, koku, doku, tat ve genel kabul edilebilirlik kriterlerinin karşılaştırılarak duyusal açıdan kişilerin tercihlerinin belirlenmesi ve sonucunda da ikame ürünlere göre tüketimde tercih edilebilirliğinin daha net ölçülebilmesi için, katılımcılara kaz eti ikramından sonra uygulanmıştır. Elde edilen verilere normallik varsayımı sağlanmadığından dolayı parametrik olmayan istatistiksel testler uygulanmış ve katılımcıların cinsiyetleri, eğitim durumları ve gelir seviyelerinin et tercihleri ve özelde kaz eti tercihi üzerinde anlamlı bir farklılık yaratıp yaratmadığ 1 tespit edilmiştir.

Anahtar Kelimeler: Kaz Eti, Tüketici Tercihi, Duyusal Analiz

\section{Sensory Analysis with Goose Consumption Preferences and Substitute Products}

\begin{abstract}
Goose breeding in the World and Turkey, remained behind the growth levels due to low relative to other poultry. However, the significant nutritional value of goose meat, the high protein level, low cholesterol content, the rich vitamin value of the liver and the fact that the goose feather are also highly valuable have also increased the importance of goose breeding in recent years. Although in many countries goose meat is consumed due to all these characteristics it is consumed as a part of the local culture in Turkey only in certain regions and across the country are not recognized enough. Goose is produced and consumed in the Eastern and Central Anatolia regions with its traditional and backyard cultivation. In recent years, it is expected to create an important market especially in the domestic and foreign markets due to demand in different regions. In this study it is aimed to conduct sensory analysis and consumption research related to goose meat consumption. The study was carried out with the participants of Traditional Goose Night Event organized in Adana, where participants from Kars, Ardahan and Iğdır provinces. The data obtained from the questionnaire forms, which were
\end{abstract}

\footnotetext{
* Bu çalışma III. International Applied Social Congress (4-6 April 2019)'de sunulmuş ve özeti basılmıştır.

**codolekoglu@atu.edu.tr tlf: (322) 4550041 Fax: (322) 455 0042, ORCID: 0000-0003-4421-2956. 


\section{European Journal of Science and Technology}

conducted by face to face interview technique, consisted of 363 people selected with the sampling technique. The questionnaires are based on comparison of the appearance, odor, texture, taste and general acceptability criteria of red meat, chicken meat and turkey meat. In order to determine the preferences of the people from the sensory point of view and as a result of the preference of the products in the consumption according to the substitution products, it was applied to the participants after the goose meat catering. As the normality assumption was not obtained, non-parametric statistical tests were applied. It was determined that the participants' gender, educational status and income levels did not make a significant difference on meat preferences and in particular goose meat preference.

Keywords- Goose Meat, Consumer Preference, Sensory Analysis 


\section{GíRiş}

Avrupa Bilim ve Teknoloji Dergisi

Uluslararası terminolojide "Kanatlı Eti" kavramı içinde tavuk, kaz, hindi, ördek, bıldırcın gibi hayvanların etleri yer almaktadır (TAGEM, 2014). Kanatlı eti nispeten düşük üretim maliyetleri, kümes hayvanlarının hızlı büyüme oranları ve etinin yüksek besin değerine sahip olmasından dolayı birçok ülkede popülaritesini artmıştır. Kanatlı eti, kalori değeri ve kolesterol seviyelerinin genellikle kırmızı etten düşük olması nedeniyle bir avantaja sahiptir. Aynı zamanda insan beslenmesinde önemli bir protein kaynağıdır. Ayrıca kümes hayvanlarının eti, kırmızı ete göre daha düşük bağ dokusu oranına sahiptir ve bu yüzden sindirimi kolaydır (Öz ve Celik, 2015). Kırmızı etin yağ asidi bileşiminin insan sağlığı açısından uygunluğu tartışmalıdır. İnsanların beslenmesinde tüketilen hayvansal gıdaların kalitesiyle sağlık arasında doğrudan bir ilişki vardır. Doymuş yağ asitleri, trans yağ asitleri ve kolesterol alımının azaltılıp, omega 3 yağ asitlerinin tüketiminin arttırılması önerilmektedir. Aksi takdirde araştırmalar bu durumun kardiyovasküler hastalıklarla ilişkili olarak en önemli risk faktörü olduğunu göstermektedir (Geldenhuys ve ark., 2015).

Kazlar ilk evcil kümes hayvanlarıdır ve diğer kümes hayvanları içinde hastalıklara ve soğuk iklim koşullarına karşı daha dirençlidir, ancak ticari olarak yetiştirilen diğer kanatlılar kadar hızlı büyümezler (Öz ve Celik, 2015). Kaz etinin iyi bir protein kaynağı olması ve özellikle arginin gibi elzem aminoasitleri içermesi, yüksek oranda doymamış yağ asitlerine sahip olmasından dolayı insan beslenmesinde çok önemli bir yere sahiptir (Liu ve ark., 2011). Kaz eti, ördek eti gibi güvenilir bir ettir. Çünkü her ikisinde de kimyasal kalıntı riski düşüktür. Bu özelliklerinin yanı sıra zengin omega-3 ve demir kaynağı olması diğer et ürünleri arasında kaz etini öne çıkaran önemli özelliklerdir (https://www.hss.gov.nt.ca).

Gelişmekte olan birçok ülke, hızla artan nüfusu beslemek için gerekli gıdalarda sürdürülebilir artışlar sağlamak açısından entegre üretim sistemlerinde hayvancılık önemlidir. Kazlar bu tür sistemlere iyi uyum sağlayan, özellikle nemli bölgelere iyi adapte olan bir özelliğe sahiptir. Doğal otlanma ile yetiştirilebilir ve diğer kuş türlerine göre hastalıklara karşı daha dirençlidirler. Kaz, Mısır'da M.Ö. 3000'e dayanan uzun geçmişine, birçok kitaba, hikâyeye ilham vermesine rağmen tavuk ve ördek kadar tüketimde popüler olamamıştır. Kaz yetiştiriciliğinin, diğer kümes hayvanlarına nazaran üreme seviyelerinin düşük olması ya da sınırlı bir coğrafi dağılımları nedeniyle çok az ekonomik öneme sahip olması bunun nedeni olarak sayılmaktadır. Açık havada en az barınak ile kışlara dayanma yeteneklerinin yanı sıra sıcak iklimlere de uyumuna rağmen ticari kaz üretimi yalnızca Asya ve Avrupa'da az sayıda ülkede önemlidir.

Tüketicilerin sağlık kaygılarının artması, dengeli ve güvenilir beslenmeye olan ilgilerinin yaygınlaşması, gıdalarda kalite ve güvenilirlik arayışlarını da artırmıştır. Tüketicilerin gıdalarda kalite ve güvenilirlik algısını da ortaya koymak tüketiciler, karar alıcılar, araştırmacılar, işletmeler ve sivil toplum kuruluşları için önemlidir. Tüketicilerin kalite algısı; satın alma esnasında kalite, tüketim kalitesi ve inanılan kalite olmak üzere üç temel başlık altında incelenebilir. Satın alma işlemi esnasında kalite belirtileri; renk, yağsızlık, marbling gibi iç faktörler ile marka, etiket, satın alma yeri, fiyat ve ihraç edilen ülke gibi dış faktörleri de içermektedir. Tüketim esnasında gözlenen tüketicinin duyusal kalite algısı açısından önemli olan özellikleri ise renk, yağsızlık, tekstür, kıkırdaksızlık, yumuşaklık, koku, aroma ve sululuktur. Satın alma ve tüketim esnasında gözlemlenemeyen fakat tüketiciyi ilgilendiren kalite özellikleri inanılan kalite olarak tanımlanmaktadır. Hormon, antibiyotik, yă̆/kolestrol, salmonella ve diğer bakteriler, hayvanın beslendiği yem, marka, üreticinin ismi, organik üretim, tazelik gibi faktörler inanılan kalite kapsamına girmektedir (Becker, 2000).

Kanatlı etlerinde en önemli kalite özellikleri görünüş, tekstür, sululuk, lezzet ve fonksiyonelliktir. Bu kriterlerden görünüş ve tekstür ürünün ilk seçimlerinde ve son ürün değerlendirmede kritik bir değere sahiptir ve görünüşün en önemli unsuru kanatlı etinin rengidir (Becker, 2000).

Etin fiziksel ve kimyasal özellikleri etin duyusal özelliklerini etkiler ve özellikle yağ asidi bileşiminin etin aroması üzerinde büyük bir etkiye sahip olduğu kabul edilmektedir. Buna ilaveten, demir gibi bazı minerallerin varlığı da et aromasını etkileyebilir. Örneğin, etteki yüksek demir içeriği, metalik bir tadın algılanmasına neden olabilir. Ayrıca etin duyusal özellikleri üzerine fiziksel hareketlilik de önemli bir diğer etkendir. Aktif ve pasif durumdaki hayvanların kas yoğunluğundaki farklılık etin yumuşak ve sert olmasına neden olur (Geldenhuys ve ark., 2014). Tüketiciler bir kanatlı ürününü pişirip yerken tekstür ve lezzetini çoğu zaman kalitesine bağlar. Etin kimyasal bileşimi et kalitesini belirlemekte ve protein, yağ, kül ve su önemli bileşenleri oluşturmaktadır (Sarıca ve ark., 2014). Duyusal analiz her üründe sıklıkla yapılan bir teknik olmakla birlikte kaz eti ve ürünlerinde literatürde az sayıda çalışmaya rastlanmıştır. Soyar ve ark (1999) tavuk but ve gögüs etlerinin mikrodalga, elektrikli fırın ve haşlama yöntemleriyle pişirildikleri çalışmada yapılan duyusal değerlendirme sonucunda, mikrodalga pişirmenin, but etlerinin renk ve genel beğeni yönlerinden elektrikli firında pişirilenlerden daha az beğenildiğini, göğüs etlerinin ise renk, tat ve koku yönlerinden daha az beğenilmesine neden olduğunu saptamıştır. Güner ve ark. (2002) kaz salamının hindi ve tavuk salamları ile kıyaslanarak tüketime elverişliliğinin belirlenmesi ve kaz etinin et ürünleri teknolojisine kazandırılmasının amaçlandığı çalışmalarında kaz etinden üretilen salam numunelerinin lezzet, tekstür ve görünüm özellikleri bakımından en düşük puanları aldığı belirlenirken, kaz etinin diğer kanatlı etleriyle kombinasyon halinde salam üretiminde kullanılabileceği sonucuna ulaşıılmışlardır. İstanbul piyasasında ambalajlı olarak satışa sunulan çeşitli firmalara ait 50 adet piliç but, 50 adet piliç kanat, 50 adet hindi kuşbaşı, 25 adet bıldırcın olmak üzere kanatlı eti örneklerinde yapılan duyusal analizler sonucunda toplam 175 adet örneğin 89 adedinin (\%50.8) koku, 88 adedinin $(\% 50,2)$ görünüş bakımından olumsuz olduğu belirlenmiştir (Sezen, 2009).

Fernandez ve ark. (2010) kesim öncesi farklı bayıltma yöntemlerinin (elektrikle, kontrollü atmosfer ve mekanik bayıltma) kaz eti ve ördek etinin kalitesine etkisini araştırmış ve bayıltma tekniklerinin pişmiş ördek etinin lezzet, sululuk ve sertlik gibi temel duyusal özelliklerini etkilemediğini belirlerken, kaz etinin duyusal özelliklerinin hiçbirinde önemli bir farklılığa neden olmadığını bulmuşlardır. Mısır kazının devekuşu, pekin ördeği, beç tavuğu ve broyler tavuk ile karşılaştırılarak yapılan duyusal değerlendirmesinde gö ğüs eti kullanılmış ve kasların fazla kullanılmasından dolayı etin yumuşaklığının az olduğu bulunmuştur. Ayrıca, kaz etinin koyu kırmızı renkli ve sert olmasından dolayı devekuşu etine benzediği ve beç tavuğu ve broyler tavuktan da farklı olduğu araştırıcılar tarafından bildirilmiştir (Geldenhuys et al., 2014). 
Bu çalışma, son yıllarda Doğu ve Orta Anadolu bölgeleri başta olmak üzere Türkiye'de de gündemde hızla yer almaya başlayan kaz yetiştiriciliğine bağlı olarak kaz ürünlerinin tüketimini belirlemek amacıyla yapılmıştır. Bu amaçla tüketicilerin tercihleri, yemek alışkanlıklarının belirlenmesi ve kaz eti deneyimlerinin duyusal analizi yapılmıştır.

\section{MATERYAL VE METOT}

Çalışmanın materyalini Kars, Ardahan ve Iğdır illerinden katılımcıların oluşturduğu, Adana'da organize edilen "Geleneksel Kaz Gecesi” etkinliğine katılanlar arasından kolayda örnekleme tekniği ile seçilen 363 kişiyle yüz yüze görüsşme tekniği ile gerçekleştirilen anket formlarından elde edilen veriler oluşturmaktadır. Anketler katılımcıların sosyo demografik bilgilerinin yanı sıra yemek tercihleri, ev dışı gıda tüketimleri ve kaz eti ile diğer kanatlı etlerin ayırıcı özelliklerini belirlemek için duyusal analiz sorularını içermiştir.

Çalışmada kullanılan duyusal analiz testi; insan duyularının bir enstrüman gibi kullanıldığı ve gıdanın şekil, renk, kıvam gibi görünüş özellikleri ile lezzet-aroma ve doku gibi duyusal özelliklerini görme, koklama, tatma, dokunma veya işitme duyularının tepkilerini ölçen, analiz eden ve açıklayan bir ölçektir.

Bu çalışmada, gıdaların beğenilip beğenilmemesi ve bundan dolayı çıkan sonuçların yorumlarının aşağıda ifade edilen durumlardan etkilenebildiği göz önünde bulundurulmalı ve bu durumlara göre değerlendirilmelidir:

- Kişilerin o andaki açlık ve susuzluk gibi fizyolojik durumlarına,

- Kişilerin alışkanlıklarına,

- Gidanın o bölgede bulunup bulunmamasına,

- Bölgenin iklimine ve mevsim değişikliklerine,

- Kişilerin ekonomik gelişmişliğine

- İçinde bulunulan sosyal ve kültürel gruplara

- Mikrobiyolojik güvenilirliğe

- Hazırlama ve servisteki kolaylığa

- Besleme değerine

\subsection{Kaz Yetiştiriciliği ve Kaz Eti}

Türkiye gerek coğrafi konumu gerekse de sahip olduğu ekolojik zenginlik açısından avantajlara sahip bir ülkedir. Boğazlarla iki kıtayı birbirine bağlayan bir köprü, dış politika ve uluslararası ilişkilerdeki iş birliği ile hava yolunda da açık hava trafiği nedeni ile dış ticarette önemli bir konuma sahiptir. Bu stratejik konum aynı zamanda sahip olunan ekolojik zenginlikle elde edilen ürünlerin dış ticaretinin artışı ile ülke ekonomisini güçlendirmek için kullanılmaktadır. Bu bağlamda tarım ve hayvancılık sektörünün ülke kalkınmasındaki katma değer katkısı ile rolü yüksektir. Bu özellikleri dikkate alındığında ürün çeşitlendirilmesinin yapılması ve doğal kaynakların sürdürülebilirliğini sağlayan ürünlerin üretilmesi de önem taşımaktadır. Türkiye hayvansal ürün üretimi açısından özellikle büyükbaş ve kümes hayvanları üretiminde maliyetlerin yüksekliği nedeni ile yeterli potansiyeli yakalayamamaktadır. Kaz yetiştiriciliği birçok iklime uyum sağlaması ve doğal kaynakları iyi değerlendirmesi açısından önemli avantajlara sahiptir. Ancak Türkiye'de kaz yetiştiriciliği belirli illerde sınırlı olarak yapılmaktadır. Özellikle tavuk ve hindi sayısı ile karşılaştıııldığında oldukça düşüktür (Tablo 1). Bu kaz ürünlerinin yurt içi perakende tüketiminin ve tercihinin yetersiz olmasından kaynaklanmaktadır. Oysa besin değerleri açısından ikame ürünlere göre yüksek avantaja sahiptir (Tablo 2).

Tablo 1. Türkiye'de bulunan kümes hayvanları (1000 adet)

\begin{tabular}{cccrc}
\hline Yıllar & Tavuk & Hindi & Kaz & Ördek ve Beç Tavuğu \\
\hline 2005 & 257.221 & 3.697 & 1.067 & 656 \\
2006 & 286.121 & 3.227 & 830 & 525 \\
2007 & 205.082 & 2.675 & 1.023 & 482 \\
2008 & 180.916 & 3.230 & 1.063 & 470 \\
2009 & 163.469 & 2.755 & 945 & 413 \\
2010 & 163.985 & 2.942 & 716 & 397 \\
2011 & 158.917 & 2.563 & 680 & 382 \\
2012 & 169.034 & 2.761 & 676 & 357 \\
2013 & 177.433 & 2.925 & 755 & 368 \\
2014 & 199.976 & 2.990 & 912 & 400 \\
2015 & 213.658 & 2.828 & 851 & 398 \\
2016 & 220.322 & 3.183 & 933 & 414 \\
2017 & 221.245 & 3.872 & 978 & 492 \\
2018 & 229.507 & 4.043 & 1.080 & 533 \\
\hline
\end{tabular}

Kaynak: TÜİK (www.tuik.gov.tr) 
Tablo 2. Çeşitli etlerin yenebilen 100 gramının sağladığı enerji ve besin öğelerinin miktarları ${ }^{3}$

\begin{tabular}{|c|c|c|c|c|c|c|}
\hline Et Türü & $\begin{array}{l}\text { Fiyat } \\
(1 \mathrm{~kg})\end{array}$ & $\begin{array}{c}\text { Enerji } \\
(\text { kal })\end{array}$ & $\begin{array}{l}\text { Protein } \\
(\mathrm{g})\end{array}$ & $\begin{array}{c}\text { Yă } \\
(g)\end{array}$ & Kalsiyum (mg) & $\begin{array}{c}\text { Demir } \\
(\mathrm{mg})\end{array}$ \\
\hline Sığır (orta yağl1) & 50 & 240 & 18.7 & 18.2 & 8 & 2.6 \\
\hline Koyun (orta yağl1) & 55 & 267 & 17.0 & 21.0 & 7 & 2.2 \\
\hline Tavuk & 10 & 149 & 19.0 & 8.0 & 15 & 1.5 \\
\hline Tavşan & 40 & 137 & 21.0 & 5.8 & 17 & 1.6 \\
\hline Keçi & 55 & 157 & 18.4 & 9.2 & 1 & 2.2 \\
\hline Hindi & 25 & 144 & 19.5 & 6.7 & 17 & 1.7 \\
\hline $\mathrm{Kaz}$ & 70 & 161 & 22.8 & 7.1 & 13 & 2.6 \\
\hline
\end{tabular}

Kaynak: Baysal, 2014. Beslenme. Hacettepe Üniversitesi, Sağlık Bilimleri Fakültesi, Beslenme ve Diyetetik Bölümü, Ankara, 566s. https://www.fitekran.com/besin-degeri (Hindi ve Kaz değerleri)

Türkiye kaz eti dış ticareti 2016 yılı haricinde sadece ithalat yönlüdür (Tablo 3). 2016 yılında düşük miktarda gerçekleşen ihracat Macaristan, Bahreyn ve Birleşik Arap Emirlikleri’ne yapılmıştır. İthalat yalnızca kaz eti ve ürünlerinde önemli bir üretici olan Macaristan'dan yapılmaktadır. Macaristan Çin'den sonra en büyük kaz üreticisidir. Çin dünya kaz üretiminin \%95,4'üne sahiptir. Bölgesel olarak da üretimde yine Asya ülkeleri Çin’in liderliği nedeni ile ilk sırada yer almaktadır (\%94,6). Avrupa ülkelerinin üretimdeki payı \%3,5'tur. Dünyada 204 farklı türde kaz olduğu bilinmektedir ve dünya genelinde yetiştiricilik de yapılabilmektedir. Ancak ekonomik açıdan sadece Asya ve Orta Avrupa'da önemli bir kümes hayvanı olarak yetiştirilmektedir. Dünya kaz eti üretimi 1961 'de yalnızca 150 bin ton iken, 2000'de 1,9 milyon tona ve 2017'de de yaklaş1k 2,5 milyon tona yükselmiştir (www.fao.org). Dünya kaz eti üretiminin \%94'ü Çin'de tüketilmektedir. Bunu, Ukrayna, Misır ve Macaristan takip etmektedir. (http://www.poultryhub.org/species/commercial-poultry/goose/).

Tablo 3. Türkiye kaz eti dış ticareti

\begin{tabular}{|c|c|c|c|c|}
\hline Yil & İhracat Miktar & İhracat Dolar & İthalat Miktar & İthalat Dolar \\
\hline 2012 & & & 700 & 26.036 \\
\hline 2013 & & & 2.046 & 39.618 \\
\hline 2014 & & & 6.833 & 116.200 \\
\hline 2015 & & & 2.008 & 7.237 \\
\hline 2016 & 76 & 676 & 500 & 1.776 \\
\hline 2017 & & & 1.550 & 5.420 \\
\hline 2018 & & & 200 & 6.688 \\
\hline
\end{tabular}

\section{BULGULAR VE TARTIŞMA}

Kaz etinin evlerde tüketimi sadece ürünün yetiştiriciliğinin yapıldığı bölge ve bu bölgelerle ilişkisi olan hanelerde yoğundur. Ancak, ev dışı gıda tüketimin arttığı ve konsept yiyecek hizmetleri sunan restoranların artışı, tüketicilerin farklı ürün deneyimleme istekleri kaz eti ve kaz ürünlerinin hazır yiyecek sektöründe yer bulması kaçınılmaz olacaktır. Tablo 5'de ev dışı yemek tercihleri verilmiştir ve birden çok cevap alınmıştır. Ankete katılan tüketicilerin \% 33,7'si haftada birkaç kez ev dişında yemek yemekte (Tablo 4) ve önemli bir kısmı da $(\% 45,3)$ kaz etine ikame ürünler tüketmeyi tercih etmektedir. Bu cevaplarda en fazla Kaz eti ve ürünlerinin dünya mutfağında da önemli bir yeri olduğu dikkate alındığında bu oranın artması olasıdır.

Tablo 4. Ev dışında yemek yeme sıklığı

\begin{tabular}{lcc}
\hline & Frekans & Oran (\%) \\
\hline Ayda bir kez & 61 & 17,1 \\
Haftada bir kez & 85 & 23,9 \\
Haftada birkaç kez & 120 & 33,7 \\
Günlük & 31 & 8,7 \\
Özel günlerde & 44 & 12,4 \\
Diğer & 15 & 4,2 \\
Toplam & $\mathbf{3 5 6}$ & $\mathbf{1 0 0}$ \\
\hline
\end{tabular}

\footnotetext{
${ }^{3}$ Adana'da farklı perakendecilerden alınan fiyat ortalamalarıdır. Ancak kaz eti perakende satılmadığı için fiyatlarda Kars satışları baz alınmıştır 
Tablo 5. Ev dişında yemek tercihi

\begin{tabular}{lcc}
\hline & Frekans & Oran (\%) \\
\hline Ev yemeği & 102 & 14,19 \\
Fast-food & 104 & 14,46 \\
Kırmızı et & 231 & 32,13 \\
Deniz ürünü & 90 & 12,52 \\
Tavuk-hindi & 95 & 13,21 \\
Dünya mutfağ1 & 23 & 3,20 \\
Sokak yemeği & 74 & 10,29 \\
Toplam & $\mathbf{7 1 9}$ & \\
\hline
\end{tabular}

\subsection{Duyusal Analiz}

Anketler, katılımcılara fırında pişirme $\left(180^{\circ} \mathrm{C}\right.$ 'de 25 dakika) yöntemi uygulanmış kaz eti ikramından sonra uygulanmıştır. Kaz etini görünüş, koku, doku, tat ve genel kabul edilebilirlik kriterlerine göre duyusal açıdan değerlendirmişlerdir. Panelistler yaptıkları değerlendirmeyi çok iyi (9), iyi (7-8), orta (4-5-6) ve kötü (1-2-3) olarak puanlamışlardır. Tüm katılımcılara testin formatı ve skalanın nasıl değerlendirileceği hakkında duyusal değerlendirme öncesi bilgi verilmiştir. Elde edilen sonuçlarda kaz eti görünüş, koku, doku olarak orta düzeyde; tat açısından ise iyi, düzeyde değerlendirildiği belirlenmiştir. Genel kabul edilebilirlik olarak bakıldığında ise orta ve iyi düzey dikkat çekicidir (Tablo 6).

Tablo 6. Duyusal Analiz Değerlendirmesi (\%)

\begin{tabular}{|c|c|c|c|c|c|}
\hline & Duysal Kriterler & Kötü & Orta & $\dot{I} y i$ & Çok iyi \\
\hline Görünüş & & 12,3 & 41,8 & 30,1 & 15,8 \\
\hline Koku & & 16,6 & 45,4 & 23,7 & 14,2 \\
\hline Doku & & 16,6 & 41,7 & 28,2 & 13,5 \\
\hline Tat & & 15,7 & 28,9 & 33,7 & 21,7 \\
\hline
\end{tabular}

Verilere, normallik varsayımı sağlanmadığından parametrik olmayan istatistiksel testler uygulanmış ve katılımcıların sosyodemografik değişkenlerinin kaz eti tercihi üzerinde anlamlı bir farklılık yaratıp yaratmadığı Mann-Whitney U testi ile analiz edilmiştir. Sadece görünüş ve tat $(p=0,04 \leq 0,05)$ açısından cinsiyetler arasında anlamlı bir farklılık olduğu, ancak kadınların tüm duyusal değerlendirme kriterlerinde daha olumlu cevap verdikleri belirlenmiştir. Genel kabul edilebilirlikte de cinsiyetler anlamlı farklılık göstermekte ve kadınlar kaz etini erkeklere göre daha olumlu değerlendirmektedir (Tablo 7).

Tablo 7. Duyusal değerlendirmenin cinsiyete göre farklılığının analizi

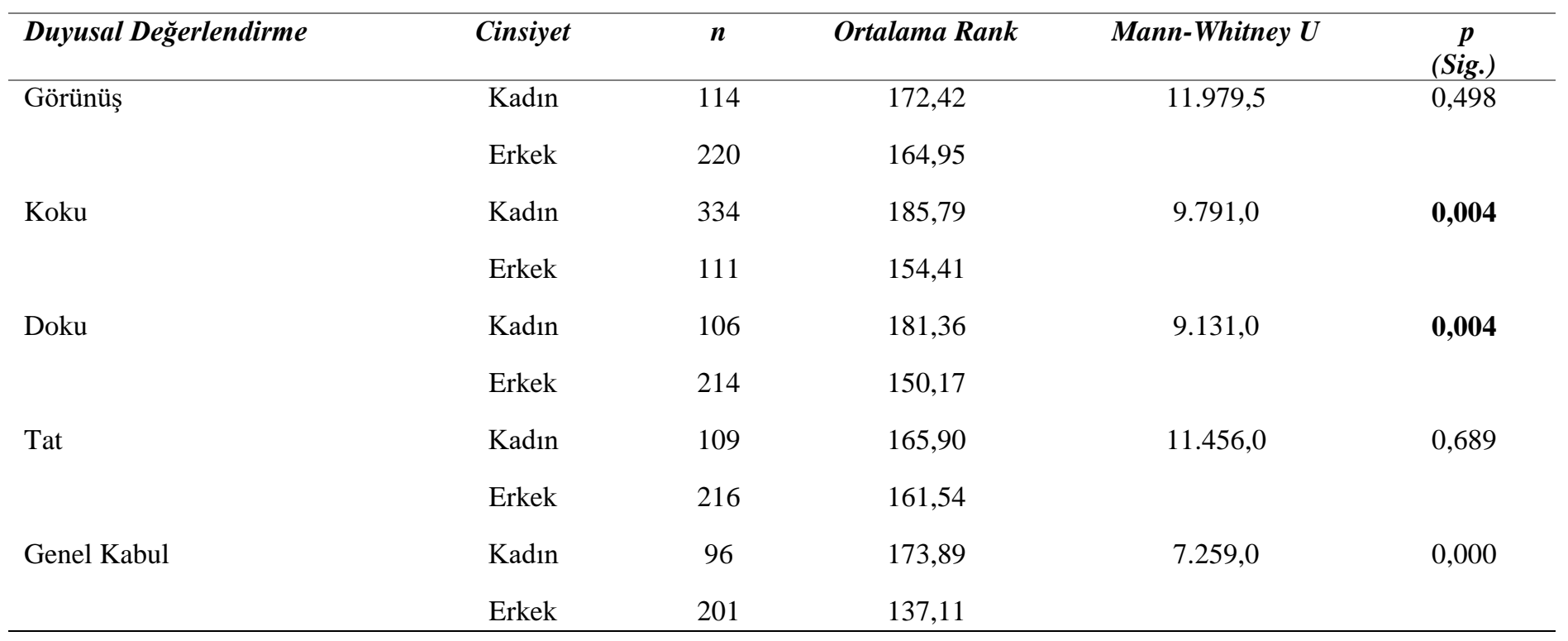


Çalışma durumu da tüketicilerin davranış ve algılarını etkileyebilecek diğer bir değişken olarak alınmıştır. Çalışma durumu ve tat arasında anlamlı ilişki bulunmazken $(p=0,137>0,05)$ diğer duyusal kriterler anlamlı çıkmıştır. Çalışanlar duyusal kriterleri daha olumlu değerlendirmişlerdir (Tablo 8). Çalışma hayatı günlük en az bir ögüunün ev dışında yenmesine neden olabilmektedir. Ev dışı yemek deneyimi de farklı lezzetleri ve yemek çeşitlerini deneyimleme firsatı yaratan bir durumdur. Tablo 8'de sonuçlara göre genel kabul edilebilirlik anlamlı farklılık göstermekte ve çalışanlar kaz etini daha olumlu değerlendirmektedir.

Tablo 8. Duyusal değerlendirmenin çalışma durumuna göre farklılığının analizi

\begin{tabular}{|c|c|c|c|c|c|}
\hline Duyusal Değerlendirme & Çalışma Durumu & $n$ & Ortalama Rank & Mann-Whitney $U$ & $\underset{\text { (Sig.) }}{p}$ \\
\hline \multirow[t]{2}{*}{ Görünüş } & Çalışıyor & 101 & 184,28 & 9768,5 & 0.020 \\
\hline & Çalışmıyor & 230 & 157,97 & & \\
\hline \multirow[t]{2}{*}{ Koku } & Çalışıyor & 100 & 185,69 & 9081,0 & 0.004 \\
\hline & Çalışmıyor & 226 & 153,68 & & \\
\hline \multirow[t]{2}{*}{ Doku } & Çalışıyor & 97 & 186,69 & 7984,0 & 0.000 \\
\hline & Çalışmıyor & 220 & 146,79 & & \\
\hline \multirow[t]{2}{*}{ Tat } & Çalışıyor & 95 & 173,28 & 9663,0 & 0,137 \\
\hline & Çalışmıyor & 227 & 156,57 & & \\
\hline \multirow[t]{2}{*}{ Genel Kabul } & Çalışıyor & 84 & 176,87 & 6353,0 & $\mathbf{0 , 0 0 0}$ \\
\hline & Çalışmıyor & 210 & 135,75 & & \\
\hline
\end{tabular}

Öğrenim durumuna göre doku dışında duyusal değerlendirme kriterleri arasında istatistiksel olarak anlamlı bir farklılık olduğu görülmektedir. Duyusal değerlendirme kriterlerinden tat ve genel kabul edilebilirlikte lise mezunları, görünüş ve kokuda ise lisans/lisansüstü mezunları diğerlerine göre daha yüksek ortalama değerine ulaşmış ve istatistiksel olarak anlamlı farklılık göstermiştir (Tablo 9).

Tablo 9. Duyusal değerlendirmenin öğrenim durumuna göre farklılı̆̆ının analizi

\begin{tabular}{|c|c|c|c|c|c|}
\hline Duyusal Değerlendirme & Öğrenim Durumu & $n$ & Ortalama Rank & Ki-Kare & $P$ (Sig.) \\
\hline \multirow[t]{3}{*}{ Görünüş } & İlköğretim & 196 & 159,99 & 8,375 & 0.015 \\
\hline & Lise & 129 & 159,41 & & \\
\hline & Lisans ve Lisansüstü & 12 & 236,58 & & \\
\hline \multirow[t]{3}{*}{ Koku } & İlköğretim & 191 & 150,79 & 14,218 & 0.001 \\
\hline & Lise & 129 & 184,37 & & \\
\hline & Lisans ve Lisansüstü & 12 & 224,42 & & \\
\hline \multirow[t]{3}{*}{ Doku } & İlköğretim & 183 & 152,70 & 3,893 & 0.143 \\
\hline & Lise & 127 & 172,59 & & \\
\hline & Lisans ve Lisansüstü & 12 & 178,25 & & \\
\hline \multirow[t]{3}{*}{ Tat } & İlköğretim & 194 & 152,18 & 7,378 & 0.025 \\
\hline & Lise & 120 & 181,51 & & \\
\hline & Lisans ve Lisansüstü & 12 & 166,42 & & \\
\hline \multirow[t]{3}{*}{ Genel Kabul } & İlköğretim & 178 & 138,12 & 9,537 & 0.008 \\
\hline & Lise & 111 & 169,86 & & \\
\hline & Lisans ve Lisansüstü & 10 & 140,95 & & \\
\hline
\end{tabular}


Sadece kaz etine duyusal analiz yapılmış ancak tüketicilerin lezzet, yağllık ve yumuşaklık açısından ikame ürün olarak alınan kırmızı et, hindi ve tavuk eti ile 5'li Likert ölçeğinde karşılaştırmaları da değerlendirilmiş̧ir. Bu değerlendirmeye göre kaz eti lezzet açısından hindi ve tavuk etine göre daha lezzetli, kırmızı ete göre ise daha az lezzetli olarak değerlendirilmiştir. Yağllık değerlendirmesinde ise kırmızı ete göre daha yağsız, tavuk etine göre daha yağlı olarak belirtilmiştir. Yumuşaklık değerlendirmesinde ise kırmızı et ve hindi etine göre daha yumuşak ancak tavuk etine göre daha sert olduğu yönünde değerlendirilmiştir (Tablo 11). Bu sonuçların kaz eti tüketim sıklığı ile değerlendirilmesi anlamlı sonuçlar vermektedir. Çünkü katılımcıların \%48,6'sı ilk defa kez eti tüketmektedir. Sıklıkla tüketenlerin sayısı oldukça düşüktür. (Tablo 10).

Tablo 10. Kaz etinin tüketim sıklığı

\begin{tabular}{ccc}
\hline & Frekans & Oran (\%) \\
\hline Ayda bir kez & 16 & 4,6 \\
Haftada bir kez & 6 & 1,7 \\
Özel günlerde & 158 & 45,1 \\
İlk defa yiyorum & 170 & 48,6 \\
Toplam & $\mathbf{3 5 0}$ & $\mathbf{1 0 0}$ \\
\hline
\end{tabular}

Tablo 11. Kaz etinin ikame etlere göre lezzet, yağ ve yumuşaklık değerlendirilmesi (\%)

\begin{tabular}{|c|c|c|c|c|c|c|}
\hline \multicolumn{2}{|c|}{ Kaz eti, } & \multirow{2}{*}{$\begin{array}{c}\begin{array}{c}\text { Kesinlikle } \\
\text { Katılmıyorum }\end{array} \\
17,7\end{array}$} & \multirow{2}{*}{$\begin{array}{c}\text { Katılmıyorum } \\
11,9\end{array}$} & \multirow{2}{*}{$\begin{array}{c}\text { Kararsizım } \\
19,8\end{array}$} & \multirow{2}{*}{$\begin{array}{c}\text { Katiliyorum } \\
20,6\end{array}$} & \multirow{2}{*}{$\begin{array}{c}\begin{array}{c}\text { Kesinlikle } \\
\text { Katıllyorum }\end{array} \\
29,9\end{array}$} \\
\hline & $\begin{array}{l}\text { Tavuk etine göre } \\
\text { daha lezzetlidir }\end{array}$ & & & & & \\
\hline \multirow{2}{*}{ 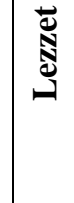 } & $\begin{array}{l}\text { Kırmızı ete göre } \\
\text { daha lezzetlidir }\end{array}$ & 33,2 & 19,9 & 20,8 & 11,0 & 15,0 \\
\hline & $\begin{array}{l}\text { Hindi etine göre } \\
\text { daha lezzetlidir }\end{array}$ & 15,0 & 12,0 & 24,9 & 18,9 & 29,1 \\
\hline \multirow{3}{*}{ עָ } & $\begin{array}{l}\text { Tavuk etine göre } \\
\text { daha yağlıdır }\end{array}$ & 13,9 & 16,9 & 26,0 & 21,9 & 21,3 \\
\hline & $\begin{array}{l}\text { Kırmızı ete göre } \\
\text { daha yağlıdır }\end{array}$ & 18,3 & 21,6 & 29,4 & 16,2 & 14,4 \\
\hline & $\begin{array}{l}\text { Hindi etine göre } \\
\text { daha yağlıdır }\end{array}$ & 10,7 & 17,7 & 30,8 & 24,1 & 16,8 \\
\hline \multirow{3}{*}{ 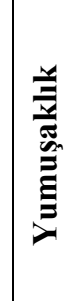 } & $\begin{array}{l}\text { Tavuk etine göre } \\
\text { daha yumuşaktır }\end{array}$ & 18,3 & 20,1 & 27,3 & 20,1 & 14,1 \\
\hline & $\begin{array}{l}\text { Kırmızı ete göre } \\
\text { daha yumuşaktır }\end{array}$ & 16,4 & 14,3 & 29,5 & 22,8 & 17,0 \\
\hline & $\begin{array}{l}\text { Hindi etine göre } \\
\text { daha yumuşaktır }\end{array}$ & 13,8 & 14,1 & 29,3 & 20,1 & 22,8 \\
\hline
\end{tabular}

\section{SONUÇ}

Türkiye, ekolojik uygunluğu, küçük işletmeler için fizibil olabilmesi, dış ticaret açısından AB ve Ortadoğu pazarı için uygun jeolojik özelliği ile kaz üretiminde ideal koşullara sahiptir. Diğer yandan tüketim kalıplarındaki değişimler, ev dışı tüketimin yaygınlaşması, sağlıklı gıda tüketim eğiliminin artması, artan nüfusunun hayvansal protein ihtiyacında alternatif olması, yeni ürün arayan tüketicilerin varlığı, yöresel lezzetlerin turizm aracı olarak kullanımının yaygınlaşması Türkiye'de kaz üretim ve tüketim potansiyelinin varlığını ve gelecek yıllarda da artarak devam edeceğini ortaya koymaktadır. İkame ürünlere göre sahip olduğu besin değerlerindeki avantaj, katılımcıların ikame ürünlere göre olumlu değerlendirmeleri dikkate alındığında kaz etinin pazarda yer bulacağı şüphesizdir. Duyusal analiz sonuçlarında kadınların erkeklere göre kabul edilebilirlik düzeyleri daha yüksek çıkmıştır. Kadınlar gıda satın alımında ve hazırlanmasında en büyük sorumluluğa sahip aile bireyidir. Bu özellik dikkate alındığında kaz ürünlerinin marketlerde yer alması kabul edilebilirliği, satın alınabilirliği açısından oldukça umut vericidir. İkame ürünlere göre fiyatının yüksekliği bir dezavantaj olarak görülebilir ancak, arzın artışı ile fiyatların da düşmesi olasıdır. 


\section{Avrupa Bilim ve Teknoloji Dergisi}

Bu bağlamda, ilgili bakanlıklarda karar alıcıların destekleme politikalarında kaz yetiştiriciliğine yer vermesi temel beklentidir. Ancak, bölgesel kalkınma ajanslarının ve KOSGEB'in destek programına alması sadece üreticilerin değil işletme ve perakendecilerin de desteklenmesini sağlayacaktır. Bu çalışmada fiyat karşılaştırması değerlendirme dışı bırakılmıştır. Kaz etinin ikame ürünlere göre pazar fiyatı açısından değerlendirilmesi, talep esnekliğinin ortaya konması üretimin artışı koşulunda perakende fiyatını hangi yönde etkileyeceğini belirlemek de karar alıcı ve işletmeler için önemli bir bulgu olacaktır.

\section{TEŞEKKÜR}

Bu çalışma Adana Alparslan Türkeş Bilim ve Teknoloji Üniversitesi Bilimsel Araştırma Projeleri Koordinasyon Birimi (BAP) tarafindan kabul edilen 18113008 nolu BAP projesi kapsamında desteklenmektedir.

\section{Kaynaklar}

Becker, T. 2000. Consumer Perception of Fresh Meat Quality: A Framework for Analysis, British Food Journal, 102(2):158-176.

Geldenhuys, G., Hoffman, L.C., Muller, M., 2014. Sensory profiling of Egyptian goose (Alopochen aegyptiacus) meat. Food Research International, 64: 25-33.

Geldenhuys, G., Hoffman, L.C., Muller, N., 2015. The fatty acid, amino acid, and mineral composition of Egyptian goose meat as affected by season, gender, and portion. Poultry Science 94:1075-1087. http://dx.doi.org/10.3382/ps/pev083.

Liu B.Y., Wang, Z.Y., Yang, H.M., Wang, J.M. Xu, D., Zhang, R., Wang, Q., 2011. Influence of rearing system on growth performance, carcass traits, and meat quality of Yangzhou. Poultry Science, 90(3): 653-659. https://doi.org/10.3382/ps.2009-00591

Tarımsal Araştırmalardan Bakış, 2014, www.tarim.gov.tr/TAGEM.

Oz, F., Celik, T., 2015. Proximate composition, color and nutritional profile of raw and cooked goose meat with different methods. Journal of Food Processing and Preservation, 39: 2442-2454.

Sarıca, M., Boz, M.A, Yamak, U.S., 2014. Yzgat ilinde halk elinde yetiştirilen beyaz ve alaca kazların et kalite özellikleri ve bazı kan parametreleri. Anadolu Tarim Bilim. Derg., 29(2): 147-153. DOI: 10.7161/anajas.2014.29.2.147-153.

Soyer, A., Kolsarıı, N., Candoğan, K., 1999. Tavuk Etlerinin Bazı Kalite Özellikleri ve Besin Öğelerine Geleneksel ve Mikrodalga ile Pişirme Yöntemlerinin Etkisi. Tr. J. of Agriculture and Forestry, 23(2):289-296.

Güner., A., Doğruer, Y., Uçar, G., Yörük, H.D., 2002. Salam Üretiminde Kaz Etinin Kullanılabilme İmkanları. Turk J Vet Anim Sci., 26:1303-1308.

Sezen, G., 2009. Piyasada Satışa Sunulan Taze Kanatlı Eti Preparatlarının Son Kullanma Tarihlerindeki Duyusal, Kimyasal ve Mikrobiyolojik Kaliteleri. Uludag Univ. J. Fac. Vet. Med., 28(1): 19-24.

Fernandez, X, Lahirigoyen, E., Auvergne, A., Molett, C., Bouillier-Oudot, M., 2010. The effects of stunning methods on product qualities in force fed ducks and geese. 1. Carcass downgrading and meat quality. Animal, 4:1, pp 128-138. doi:10.1017/S1751731109990851

G. Geldenhuys, G., Hoffman, L.C., M. Muller, M., 2014. Sensory profiling of Egyptian goose (Alopochen aegyptiacus) meat.

(http://www.poultryhub.org/species/commercial-poultry/goose/).

http://www.fao.org

http://www.tuik.gov.tr

https://www.hss.gov.nt.ca 